\title{
Peningkatan Hasil Belajar Matematika dan Respon Siswa Melalui Pembelajaran Kooperatif Tipe STAD dengan Metode Penemuan Terbimbing
}

\author{
Yuni Rhamayanti ${ }^{1, a)}$ \\ ${ }^{1}$ Universitas Graha Nusantara Padangsidimpuan \\ a) ritongayunirhamayanti@gmail.com
}

\begin{abstract}
This study was conducted on junior high school students with the aim to improve the learning outcomes of mathematics, student activities and student responses through the application of STAD type cooperative learning model with guided discovery method. This type of research is Classroom Action Research, ie research done by teachers in their own class with planned, systematic to improve / improve the quality of classroom learning practice. The subjects of this study are students of class VII SMP Negeri Padangsidimpuan Lesson Year 2017-2018, selected is a class VII-2 with the number of students 31 people. While the object of this study is the application of STAD type cooperative learning model with guided discovery method to improve results and student learning activities that are not good math and need to be improved. The research instrument in this research will use test and non test technique. The conclusion that can be drawn from this research is 1) the increase of mathematics learning outcomes through the application of STAD type cooperative learning model with guided discovery method of 0.65 with medium criteria, 2) Increased student learning activity through the application of STAD type cooperative learning model with guided discovery method equal to 0.46 with medium criterion, 3) also increase student response to STAD type cooperative learning with guided discovery method. The improvement of teachers' ability to manage the learning is 0.78 with high criteria.
\end{abstract}

Keywords: mathematics learning outcome, students' activities, STAD, guided discovery

\begin{abstract}
Abstrak. Penelitian ini dilakukan pada siswa tingkat SMP dengan tujuan untuk meningkatkan hasil belajar matematika, aktivitas siswa serta respon siswa melalui penerapan model pembelajaran kooperatif tipe STAD dengan metode penemuan terbimbing. Jenis penelitian ini adalah penelitian tindakan kelas (classroom action research), yaitu penelitian yang dilakukan oleh guru di kelasnya sendiri dengan terencana, sistematis untuk memperbaiki/ meningkatkan mutu praktik pembelajaran di kelasnya. Adapun Subjek penelitian ini adalah siswa kelas VII SMP Negeri Padangsidimpuan Tahun Pelajaran 2017-2018, yang dipilih adalah kelas VII-2 dengan jumlah siswa 31 orang. Sedangkan objek penelitian ini adalah penerapan model pembelajaran kooperatif tipe STAD dengan metode penemuan terbimbing untuk peningkatan hasil dan aktivitas belajar matematika siswa yang kurang baik dan perlu diperbaiki. Instrumen penelitian pada penelitian ini akan menggunakan teknik tes dan non tes. Simpulan yang dapat diambil dari penelitian ini adalah 1) meningkatnya hasil belajar matematika melalui penerapan model pembelajaran kooperatif tipe STAD dengan metode penemuan terbimbing sebesar 0,65 dengan kriteria sedang, 2) Meningkatnya aktivitas belajar siswa melalui penerapan model pembelajaran kooperatif tipe STAD dengan metode penemuan terbimbing sebesar 0,46 dengan kriteria sedang, 3) meningkatnya juga respon siswa terhadap pembelajaran kooperatif tipe STAD dengan metode penemuan terbimbing. Adapun peningkatan kemampuan guru mengelola pembelajaran adalah sebesar 0,78 dengan kriteria tinggi
\end{abstract}

Kata kunci: belajar matematika, aktivitas belajar, STAD, penemuan terbimbing 


\section{PENDAHULUAN}

Matematika adalah salah satu mata pelajaran yang sangat penting dalam dunia pendidikan. Cockrof mengatakan bahwa: "Matematika perlu diajarkan kepada siswa karena 1) selalu digunakan dalam segala segi kehidupan; 2) semua bidang studi memerlukan keterampilan matematika yang sesuai; 3) merupakan sarana komunikasi yang kuat, singkat, dan jelas; 4) dapat digunakan untuk menyajikan informasi dalam berbagai cara; 5) meningkatkan kemampuan berpikir logis, ketelitian, dan kesadaran keruangan; dan 6) memberikan kepuasan terhadap usaha memecahkan masalah yang menantang". Mengingat pentingnya peranan matematika sehingga peningkatan mutu pendidikan matematika yang berkualitas terus menerus diupayakan. Namun, dalam ajang Internasional dan nasional menunjukkan prestasi pendidikan matematika masih rendah ini dibuktikan dari data TIMSS (Trends in International Mathematics and Sains Study). Indonesia berada pada peringkat 35 dari 46 negara peserta, 14 tingkat di bawah Malaysia. Nilai rata-rata yang didapat siswa Indonesia pun kurang memuaskan, yakni hanya 397. Sedangkan rata-rata nilai seluruh negara yang disurvei 452.

Kenyataan yang kurang memuaskan ini juga bisa dilihat dari rata-rata hasil belajar matematika siswa kelas VII-2 SMP Negeri 7 Padangsidimpuan semester ganjil Tahun Pelajaran 2017-2018 masih rendah. Berikut ini adalah gambaran hasil ulangan harian pada kompetensi dasar operasi hitung bilangan bulat dan pecahan untuk indikator memberikan contoh bilangan bulat dari jumlah siswa 31 orang maka sebanyak 15 orang yang tuntas $(48,4 \%)$ dan sebanyak 16 orang yang tidak tuntas $(51,6 \%)$. Sedangkan untuk indikator menghitung kuadrat dan pangkat tiga bilangan bulat dari jumlah siswa 31 orang maka sebanyak 10 orang yang tuntas $(32,3 \%)$ dan sebanyak 21 orang yang tidak tuntas $(67,7 \%)$.

Rendahnya hasil belajar matematika yang diperoleh oleh siswa, merupakan suatu gambaran tersendiri yang menunjukkan bahwa proses pembelajaran matematika masih kurang efektif. Hal ini sejalan dengan wawancara yang dilakukan peneliti dengan salah satu guru matematika di sekolah tersebut yang menyatakan bahwa "guru pada umumnya mengajarkan materi operasi hitung bilangan bulat menerapkan model pembelajaran langsung berupa penyampaian materi lewat ceramah, contoh soal dan latihan. Dimana pengajaran ini berpusat pada guru sehingga siswa kurang aktif dalam pembelajaran itu sendiri”. Ini menunjukkan bahwa umumnya proses pembelajaran matematika yang ditemuinya masih dilakukan secara biasa, drill, bahkan ceramah. Proses pembelajaran seperti ini hanya menekankan pada tuntutan pencapaian kurikulum daripada mengembangkan kemampuan belajar siswa.

Oleh sebab itu, perlu dicari model pembelajaran yang mampu meningkatkan hasil belajar siswa. yang akhirnya mengakibatkan respon siswa dalam kegiatan belajar mengajar akan semakin baik. Salah satu model pembelajaran yang diharapkan dapat melibatkan siswa secara aktif adalah model pembelajaran berkelompok (pembelajaran kooperatif) siswa diharapkan mampu bekerja sama dan berinteraksi sosial saat pembelajaran berlangsung. "Cooperative learning adalah suatu model pembelajaran yang saat ini banyak digunakan untuk mewujudkan kegiatan belajar mengajar yang berpusat pada siswa (student oriented), terutama untuk mengatasi permasalahan yang ditemukan guru dalam mengaktifkan siswa. (Isjoni, 2011)

Salah satu bentuk model pembelajaran kooperatif ini adalah model pembelajaran kooperatif tipe Student Teams Achievement Division (STAD). Pembelajaran kooperatif tipe STAD adalah model pembelajaran yang paling sesuai untuk mengajarkan matematika seperti halnya yang dikemukakan oleh Slavin: "STAD sudah digunakan dalam berbagai mata pelajaran yang ada, 
mulai dari matematika, bahasa, seni, sampai dengan ilmu sosial dan ilmu pengetahuan ilmiah lain, dan telah digunakan mulai dari siswa kelas dua sampai perguruan tinggi. (Slavin, 2005). Penggunaan metode penemuan terbimbing dapat dijadikan sebuah inovasi dalam kegiatan belajar mengajar terhadap hasil belajar siswa. Sebab, menurut pendapat Bruner, bahwa belajar penemuan sesuai dengan pencarian pengetahuan secara aktif oleh manusia, dan dengan sendirinya memberi hasil yang paling baik. (Trianto, 2009). Metode penemuan merupakan metode mengajar yang berusaha meletakkan dasar dan mengembangkan cara berpikir ilmiah. Siswa betul-betul ditempatkan sebagai subjek yang belajar. Dalam metode ini guru bertindak sebagai fasilitator dalam menyelesaikan suatu masalah yang diberikan oleh guru (Putra, Syarifudin dan Zulfah, 2018).

Berdasarkan uraian di atas, maka tujuan penelitian ini adalah bagaimana peningkatan hasil belajar dan aktivitas belajar matematika siswa melalui penerapan model pembelajaran kooperatif tipe STAD dan metode penemuan terbimbing pada siswa kelas VII-2.

\section{METODE}

Jenis penelitian ini adalah penelitian tindakan kelas (Classroom Action Research). Pada penelitian ini jika siklus I hasil belajar matematika dan aktivitas siswa belum mencapai ketuntasan, maka dilaksanakan siklus II yang tahapan kegiatannya sama dengan tahapan siklus I. Akan tetapi pada siklus II akan dilakukan beberapa tambahan perbaikan dari tindakan sebelumnya yang ditujukan untuk memperbaiki berbagai hambatan atau kesulitan yang ditemukan pada siklus I. Siklus akan berhenti jika hasil belajar matematika dan aktivitas siswa mencapai ketuntasan secara klasikal.

Subjek penelitian ini adalah siswa kelas VII SMP Negeri Padangsidimpuan, yang dipilih adalah kelas VII-2 dengan jumlah siswa 31 orang. Adapun alasan peneliti memilih kelas ini adalah berdasarkan hasil tes awal yang dilakukan bahwa kelas tersebut memiliki hasil belajar yang masih rendah sehingga masih perlu untuk ditingkatkan. Sedangkan objek penelitian ini adalah penerapan model pembelajaran kooperatif tipe STAD dengan metode penemuan terbimbing untuk peningkatan hasil belajar matematika siswa dan respon yang kurang baik dan perlu diperbaiki.

Instrumen penelitian pada penelitian ini akan menggunakan teknik tes dan non tes. Adapun tes yang digunakan adalah tes hasil belajar matematika siswa berupa soal-soal berbentuk uraian. Sebelum tes digunakan dalam penelitian terlebih dahulu meminta pertimbangan pakar untuk pengembangan dan dilakukan uji coba instrumen untuk mengetahui validitas, realibilitas, daya beda dan tingkat kesukaran tes. Menghitung Validitas dan Realibilitas dengan secara manual, excel dan dengan menggunakan SPSS. Sedangkan Non tes adalah lembar observasi dan angket. Observasi terhadap siswa dilakukan oleh peneliti untuk melihat keaktifan siswa dalan mengikuti pelajaran. Sedangkan angket untuk melihat respon siswa terhadap kegiatan pembelajaran Kooperatif Tipe STAD dengan penemuan terbimbing.

Setiap lembar jawaban siswa dikoreksi untuk mengetahui tingkat hasil belajar matematika siswa aspek kognitif. Penentuan skor untuk hasil kerja siswa dilakukan dengan memberikan penilaian menggunakan rumus berikut:

$$
\text { Nilai }=\frac{\text { Skor mentah }}{\text { Skor maks Ideal (SMI) }} \times 100
$$


Selanjutnya tingkat penguasaan tersebut akan tercermin pada tinggi rendahnya nilai yang dicapai. Pedoman konversi yang digunakan adalah sebagai berikut:

Tabel 1. Pedoman Konversi Nilai

\begin{tabular}{cc}
\hline Skor Nilai & Kategori \\
\hline $90-100$ & Sangat Baik \\
\hline $80-89$ & Baik \\
\hline $65-79$ & Cukup Baik \\
\hline $55-64$ & Kurang \\
\hline $0-54$ & Sangat Kurang \\
\hline Nurkancana $(1986: 80)$ &
\end{tabular}

Pelaksanaan observasi ini dilakukan pada saat pembelajaran berlangsung dimana peneliti meminta bantuan dari guru matematika sebagai observer untuk mengamati apakah kondisi belajar mengajar sudah terlaksana sesuai dengan skenario pembelajaran. Dari hasil observasi yang telah dilakukan observer baik terhadap guru maupun siswa dilakukan penganalisasan dengan menggunakan rumus:

$$
96 \text { aktivitas }=\frac{\text { Frekuensi }}{\text { Jumlah frekuensi }} \times 100 \%
$$

Hasil observasi dianalisis dari aktivitas siswa dalam pembelajaran dikatakan efektif jika pembelajaran berjalan dengan baik atau sangat baik sekali. Adapun kriteria penilaian observasi yaitu:

Tabel 2. Kategori Penilaian Observasi

\begin{tabular}{cc}
\hline Skor Nilai & Kategori \\
\hline $90 \%-100 \%$ & Baik Sekali \\
\hline $80 \%-89 \%$ & Baik \\
\hline $65 \%-79 \%$ & Cukup \\
\hline $55 \%-64 \%$ & Kurang \\
\hline$\leq 54 \%$ & Sangat Kurang \\
\hline Nurkancana $(1986: 80)$ &
\end{tabular}

Sedangkan untuk menghitung peningkatan hasil belajar, aktivitas dan respon siswa melalui Model Pembelajaran Kooperatif Tipe STAD dengan penemuan terbimbing dengan menggunakan rumus gain yaitu :

$(g)=\frac{\text { Nilai Postes - Nilai Pretes }}{\text { Nilai Ideal - Nilai Pretes }}$

Tabel 3. Kriteria Gain (g)

\begin{tabular}{cl}
\hline Skor Nilai & Kategori \\
\hline$g>0,7$ & Tinggi \\
\hline $0,3<g \leq 0,7$ & Sedang \\
\hline$g \leq 0,3$ & Rendah \\
\hline
\end{tabular}




\section{HASIL DAN PEMBAHASAN}

\section{Deskripsi Hasil Penelitian Tindakan Kelas (PTK) Siklus I}

Hasil penelitian tindakan siklus I diuraikan dalam beberapa tahapan. Adapun tahapan yang dilakukan dalam proses Penelitian Tindakan Kelas (PTK) di kelas VII-2 SMP Negeri 7 Padangsidimpuan Tahun Pelajaran 2017-2018 dilaksanakan yaitu perencanaan tindakan, pelaksanaan tindakan, observasi dan refleksi. Diakhir pembelajaran siklus I berlangsung, dilaksanakan postes hasil belajar matematika siswa aspek kognitif, maka hasil yang didapat dari tes tersebut dapat dilihat pada tabel berikut ini:

Tabel 4. Pengklasifikasian Hasil Belajar Siklus I

\begin{tabular}{cccc}
\hline No & Nilai & Frekuensi & Kualifikasi \\
\hline 1 & $90-100$ & 3 & Sangat Baik \\
\hline 2 & $80-89$ & 7 & Baik \\
\hline 3 & $65-79$ & 12 & Cukup \\
\hline 4 & $55-64$ & 4 & Kurang \\
\hline 5 & $0-54$ & 6 & Sangat Kurang \\
\hline
\end{tabular}

Berdasarkan tabel diatas, dari 31 siswa yang mengikuti tes diperoleh 3 orang atau 9,68\% siswa dengan kategori "Sangat Baik", 7 orang siswa atau 22,58\% dengan kategori "Baik", 12 orang siswa atau 38,71\% dengan kategori "Cukup", 4 orang siswa atau 12,90\% dengan kategori "Kurang", dan 5 orang siswa atau 16,13\% dengan kategori "Sangat Kurang". Namun peningkatan ini belum mencapai kriteria ketuntasan yang diharapkan, karena jumlah siswa yang memperoleh kategori minimal cukup sebanyak 22 orang siswa atau 70,97\% dari 31 siswa yang mengikuti tes, sehingga belum sesuai dengan target yang telah ditetapkan $80 \%$ maka diadakan refleksi pada siklus berikutnya yaitu siklus II.

Untuk lebih jelasnya dapat dicermati grafik yang menggambarkan tingkat hasil belajar matematika siswa aspek kognitif di siklus I sebagai berikut:

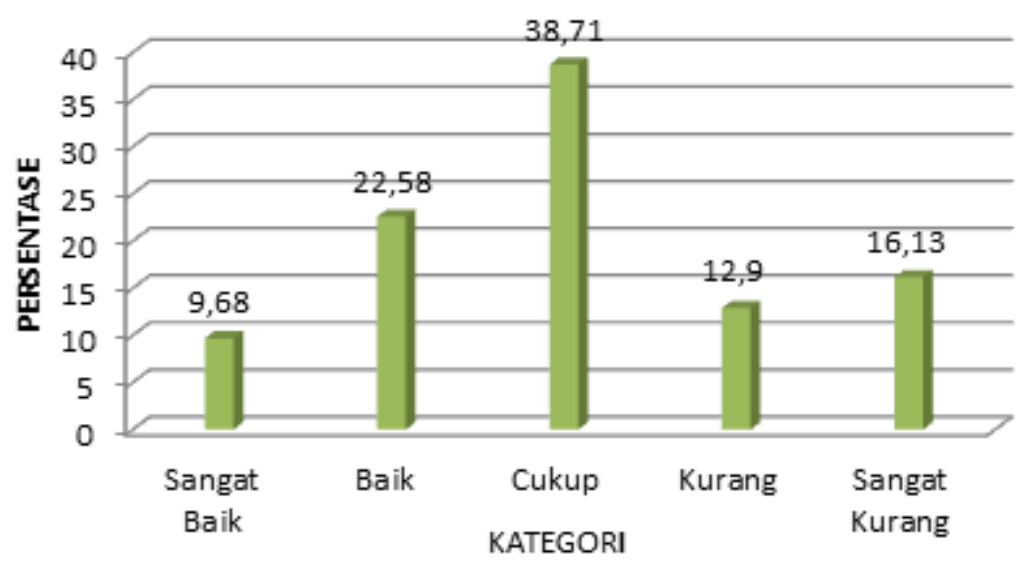

Gambar 1. Diagram Hasil Belajar

Available online at journal homepage: http://ejournal.iainkerinci.ac.id/index.php/edumatika 
Dari tabel 3 dan Gambar 1 di atas dapat diketahui bahwa hasil belajar matematika siswa aspek kognitif berada pada kategori "cukup". Untuk itu perlu adanya perbaikan dan peningkatan pada proses pembelajaran siklus berikutnya atau pada siklus II. Diharapkan pada siklus berikutnya hasil belajar matematika siswa aspek kognitif pada kategori "sangat baik" bertambah dan kategori "sangat kurang" diharapkan mengalami penurunan.

Pengamatan atau observasi merupakan bagian proses dari pengumpulan data yang diperlukan dalam penelitian. Guru matematika yang juga masuk dikelas VII yang bertindak sebagai observer mengamati siswa yang sedang mengikuti proses model pembelajaran kooperatif tipe STAD dengan metode penemuan terbimbing untuk meningkatkan hasil belajar matematika siswa aspek kognitif. Observer memiliki peran mengamati dan memotret semua aktivitas siswa yang terjadi dikelas ketika tindakan dilakukan.

Adapun hasil pengamatan observer terhadap aktivitas siswa dalam pembelajaran selama 4 kali pertemuan bahwa persentase nilai aktivitas siswa pada siklus I adalah 73,55\% dengan kategori nilai "cukup", untuk itu diharapkan pada siklus berikutnya aktivitas siswa meningkat atau sesuai dengan indikator keberhasilan. Adapun rentang hasil obsevasi aktivitas siswa pada siklus I yaitu sebagai berikut:

Tabel 5. Aktivitas Belajar Siklus I

\begin{tabular}{cccc}
\hline No & Interval & Frekuensi & \% \\
\hline 1 & $24-25$ & 6 & 19,35 \\
\hline 2 & $26-27$ & 4 & 12,9 \\
\hline 3 & $28-27$ & 6 & 19,35 \\
\hline 4 & $30-31$ & 8 & 25,82 \\
\hline 5 & $32-33$ & 5 & 16,13 \\
\hline 6 & $34-35$ & 2 & 6,45 \\
\hline & Jumlah & $\mathbf{3 1}$ & $\mathbf{1 0 0}$ \\
\hline
\end{tabular}

Sedangkan hasil observasi aktivitas siswa pada siklus I digambarkan dalam grafik histogram sebagai berikut:

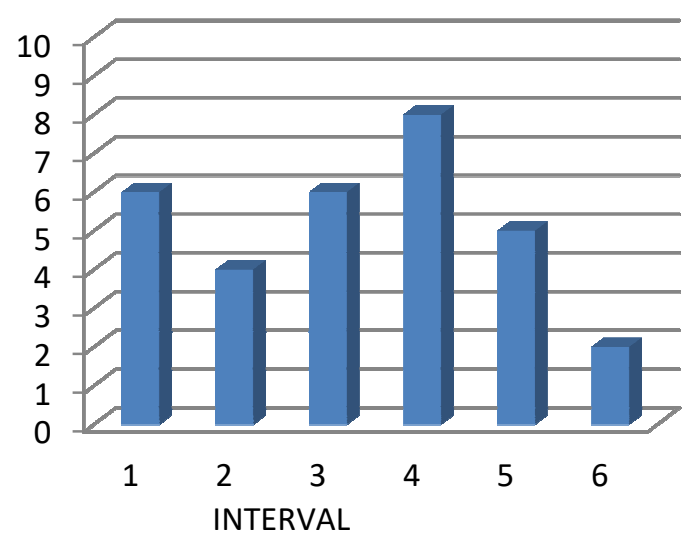

Gambar 2. Diagram Aktivitas Belajar

Dari tabel 4 dan diagram 2 di atas dapat dilihat interval 24 - 25 mempunyai frekuensi 6 atau $19,35 \%$, interval $26-27$ mempunyai frekuensi 4 atau $12,9 \%$, interval $28-29$ mempunyai 
frekuensi 6 atau 19,35\%, interval 30 - 31 mempunyai frekuensi 8 atau 25,82\%, interval $32-33$ mempunyai frekuensi 5 atau 16,13\%, interval 34 - 35 mempunyai frekuensi 2 atau 6,45\%.

Angket respon siswa dalam kegiatan pembelajaran dan terhadap perangkat pembelajaran diisi oleh siswa setelah kegiatan pembelajaran siklus I selesai. Jumlah siswa yang yang mengisi angket respon siswa adalah 31 orang. Proporsi jawaban terhadap masing-masing komponen pembelajaran disajikan dalam tabel berikut ini:

Tabel 6. Hasil Respon Siswa Siklus I

\begin{tabular}{|c|c|c|c|c|c|}
\hline \multirow{2}{*}{ No } & \multirow{2}{*}{$\begin{array}{c}\text { Aspek yang dinilai } \\
\text { Perasaan siswa } \\
\end{array}$} & \multicolumn{2}{|c|}{ Senang } & \multicolumn{2}{|c|}{ Tidak Senang } \\
\hline & & Frekuensi & Persentase & Frekuensi & Persen \\
\hline & Materi pelajaran & 25 & 80,64 & 6 & 19,36 \\
\hline & LAS & 24 & 77,42 & 7 & 22,58 \\
\hline & Suasana belajar & 25 & 80,64 & 6 & 19,36 \\
\hline & Cara guru mengajar & 23 & 74,19 & 8 & 25,81 \\
\hline & Rata-rata & 24,25 & 78,22 & 6,75 & 21,78 \\
\hline \multirow[t]{6}{*}{2} & Pendapat siswa & Frekuensi & Persentase & Frekuensi & Persen \\
\hline & Materi pelajaran & 15 & 48,39 & 16 & 51,61 \\
\hline & LAS & 31 & 100,00 & 0 & 0,00 \\
\hline & Suasana belajar & 31 & 100,00 & 0 & 0,00 \\
\hline & Cara guru mengajar & 31 & 100,00 & 0 & 0,00 \\
\hline & Rata-rata & 27 & 87,10 & 4 & 12,90 \\
\hline \multirow[t]{2}{*}{3} & Siswa berminat mengikuti & Frekuensi & Persentase & Frekuensi & Persen \\
\hline & dengan penemuan terbimbing & 23 & 74,19 & 8 & 25,81 \\
\hline \multirow[t]{5}{*}{4} & Pendapat siswa tentang LAS & Frekuensi & Persentase & Frekuensi & Persen \\
\hline & Siswa memahami LAS & 25 & 80,64 & 6 & 19,36 \\
\hline & Siswa tertarik pada LAS & 24 & 77,42 & 7 & 22,58 \\
\hline & Rata-rata & 24,50 & 79,03 & 6,50 & 20,97 \\
\hline & Rata-rata Total & 24,69 & 79,64 & 6,31 & 20,36 \\
\hline
\end{tabular}

Perhitungan respon siswa terhadap komponen dan kegiatan melalui pembelajaran Kooperatif Tipe STAD dengan metode penemuan terbimbing adalah 79,64 \% ini menunjukkan respon siswa kurang positif karena persentase rata-rata yang diperoleh lebih kecil dari $80 \%$.

Pada siklus 1 hasil refleksi yang ditemukan oleh peneliti, siswa masih ribut dalam kelas dikarenakan masih banyak siswa yang diganggu oleh temannya sendiri yang mengakibatkan siswa tersebut tidak mampu menguasai materi dan pada saat diberi tes hasil belajar matematika aspek kognitif siklus I masih banyak siswa yang belum mampu menjawab sesuai dengan langkah-langkah kunci jawaban. Hal ini dikarenakan siswa tidak mengerti maksud dan bahasa soal yang diujikan sehingga siswa cenderung malas dalam menyelesaikan soal. Sehubungan dengan itu peneliti mengadakan revisi terhadap soal-soal yang diujikan agar ditingkatkan dan lebih mudah dipahami oleh siswa maka peneliti melanjutkan ke siklus II atau siklus berikutnya.

Dari hasil observasi aktivitas siswa dalam pembelajaran matematika pada melalui Model pembelajaran kooperatif tipe STAD dengan metode Penemuan Terbimbing terlihat belum dapat 
mencapai tujuan yang diharapkan. Dari kategori aspek yang dinilai kualifikasi nilai yang diperoleh masih kurang. Hal ini menunjukkan aktivitas siswa masih pasif dalam pembelajaran, untuk itu pada siklus selanjutnya atau pada siklus II akan ditingkatkan. Jika aktivitas meningkat, maka hasil belajar matematika siswa akan meningkat.

Ditinjau dari hasil angket siswa yang diperoleh bahwa respon siswa terhadap pembelajaran kooperatif tipe STAD dengan metode Penemuan Terbimbing masih kategori cukup. Hal ini dikarenakan siswa masih merasa ragu, asing dan belum terbiasa melaksanakan pembelajaran tersebut. Dengan demikian untuk meningkatkan aspek penilaian mengenai respon siswa tersebut maka akan dilanjutkan ke siklus selanjutnya atau siklus II.

\section{Deskripsi Hasil Penelitian Tindakan Kelas (PTK) Siklus II}

Hasil penelitian diuraikan dalam tahapan yang berupa siklus-siklus pembelajaran yang dilakukan dalam proses belajar yang dilaksanakan di kelas sebelum diterapkan Model pembelajaran kooperatif tipe STAD dengan metode Penemuan Terbimbing. Siklus kedua dalam penelitian ini terdiri dari perencanaan, pelaksanaan, pengamatan dan refleksi.

Evaluasi tes hasil belajar matematika siswa aspek kognitif pada siklus II dapat diklasifikasi sebagai berikut:

Tabel 7. Pengklasifikasian Hasil Belajar

\begin{tabular}{|c|c|c|c|}
\hline No & Nilai & Frekuensi & Kualifikasi \\
\hline 1 & $90-100$ & 4 & Sangat Baik \\
\hline 2 & $80-89$ & 11 & Baik \\
\hline 3 & $65-79$ & 11 & Cukup \\
\hline 4 & $55-64$ & 5 & Kurang \\
\hline 5 & $0-54$ & 0 & Sangat Kurang \\
\hline \multicolumn{2}{|c|}{ Total } & 31 & \\
\hline
\end{tabular}

Untuk lebih jelasnya dapat dicermati diagram batang di bawah ini yang menggambarkan tingkat hasil belajar matematika siswa pada siklus II sebagai berikut:

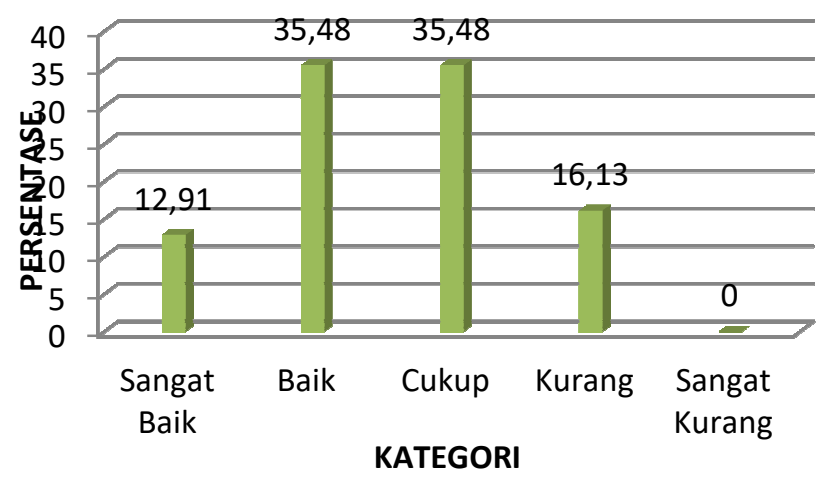

Gambar 3. Diagram Hasil Belajar

Berdasarkan tabel 6 dan diagram 3 diatas, dari 31 siswa yang mengikuti tes diperolah 4 orang atau 12,91\% siswa dengan kategori "Sangat Baik", 11 orang siswa atau 35,48\% pada kategori "Baik", 11 orang siswa atau 35,48\% pada kategori "cukup", 5 orang siswa atau 
16,13\% pada kategori "kurang". Karena jumlah siswa yang memperoleh kategori minimal cukup baik sebanyak 26 siswa atau $83,87 \%$ dari 31 siswa yang mengikuti tes. Berdasarkan hasil tersebut penelitian ini diberhentikan karena sudah memenuhi kriteria yang telah ditentukan.

Hasil pengamatan terhadap aktivitas siswa dalam pembelajaran selama 4 kali pertemuan bahwa persentase nilai aktivitas siswa pada siklus II adalah 85,75\%. Penelitian dihentikan pada siklus ini karena hasil aktivitas siswa dalam pembelajaran telah mencapai kategori "Baik" atau sudah mencapai nilai minimal $80 \%$. Hasil yang didapat sesuai dengan hasil yang diharapkan maka siklus ini dihentikan. Adapun rentang hasil obsevasi aktivitas yaitu:

Tabel 8. Tabel Aktivitas Belajar

\begin{tabular}{cccc}
\hline No & Interval & Frekuensi & \% \\
\hline 1 & $33-33,25$ & 6 & 19,35 \\
\hline 2 & $33,5-33,75$ & 5 & 16,13 \\
\hline 3 & $34-34,25$ & 7 & 22,58 \\
\hline 4 & $34,5-34,75$ & 5 & 16,13 \\
\hline 5 & $35-35,25$ & 2 & 6,46 \\
\hline 6 & $35,5-36$ & 6 & 19,35 \\
\hline \multicolumn{5}{c}{ Jumlah } & 31 & 100 \\
\hline
\end{tabular}

Sedangkan hasil observasi aktivitas siswa pada siklus II digambarkan dalam grafik histogram sebagai berikut:

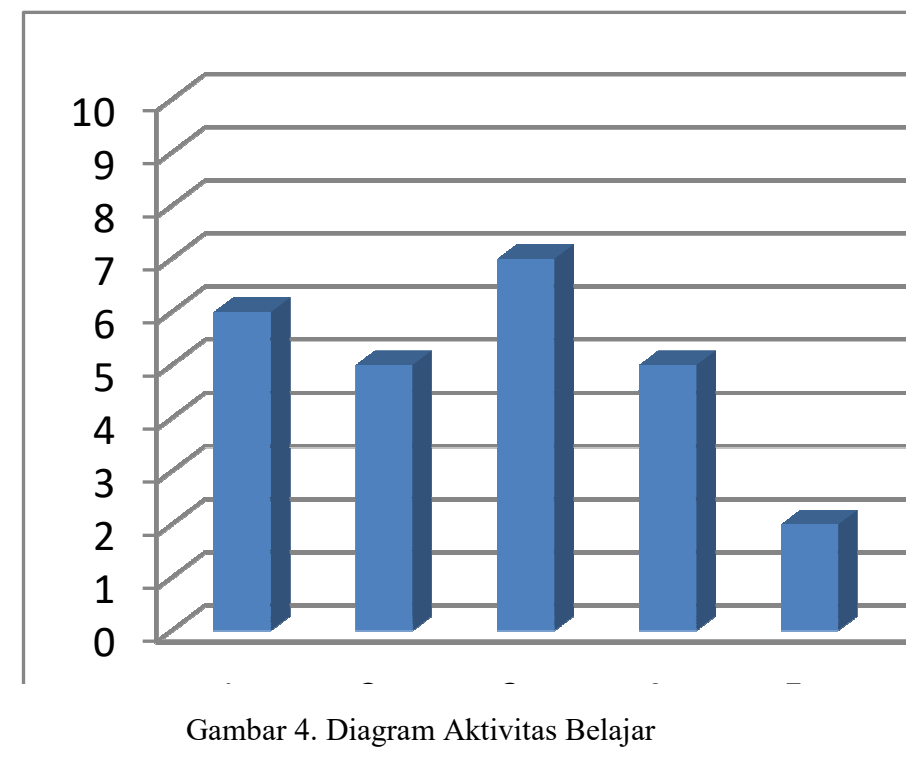

Dari table 7 dan Gambar 4 di atas dapat dilihat interval 33-33,25 mempunyai frekuensi 6 atau 19,35\%, interval 33,5-33,75 frekuensi 5 atau 16,13\%, interval 34-34,25 frekuensi 7 atau $22,58 \%$, interval 34,5-34,75 frekuensi 5 atau 16,13\%, interval 35-35,25 frekuensi 2 atau 6,46\%, interval 35,5-36 mempunyai frekuensi 6 atau 19,35\%.

Angket respon siswa dalam kegiatan pembelajaran dan terhadap perangkat pembelajaran diisi oleh siswa setelah kegiatan pembelajaran siklus II selesai. Jumlah siswa yang yang mengisi angket respon siswa adalah 31 orang. Proporsi jawaban terhadap masing-masing komponen pembelajaran disajikan dalam tabel berikut ini: 
Tabel 9. Hasil Respon Siswa Siklus II

\begin{tabular}{|c|c|c|c|c|c|}
\hline \multirow{2}{*}{ No } & \multirow{2}{*}{$\begin{array}{c}\text { Aspek yang dinilai } \\
\text { Perasaan siswa }\end{array}$} & \multicolumn{2}{|c|}{ Senang } & \multicolumn{2}{|c|}{ Tidak Senang } \\
\hline & & Frekuensi & Persentase & Frekuensi & Persen \\
\hline & Materi pelajaran & 31 & 100,00 & 0 & 0,00 \\
\hline & LAS & 28 & 90,32 & 3 & 9,68 \\
\hline & Suasana belajar & 31 & 100,00 & 0 & 0,00 \\
\hline & Cara guru mengajar & 29 & 93,55 & 2 & 6,45 \\
\hline & Rata-rata & 29,75 & 95,97 & 1,25 & 4,03 \\
\hline \multirow[t]{6}{*}{2} & Pendapat siswa & Frekuensi & Persentase & Frekuensi & Persen \\
\hline & Materi pelajaran & 31 & 100,00 & 0 & 0,00 \\
\hline & LAS & 26 & 84,44 & 5 & 15,56 \\
\hline & Suasana belajar & 31 & 100,00 & 0 & 0,00 \\
\hline & Cara guru mengajar & 28 & 93,33 & 3 & 6,67 \\
\hline & Rata-rata & 31,25 & 94,44 & 1,75 & 5,56 \\
\hline \multirow[t]{2}{*}{3} & Siswa berminat untuk mengikuti & Frekuensi & Persentase & Frekuensi & Persen \\
\hline & $\begin{array}{l}\text { pembelajaran koperatif tipe } \\
\text { STAD dengan metode penemuan } \\
\text { terbimbing }\end{array}$ & 29 & 100 & 0 & 0,00 \\
\hline \multirow[t]{5}{*}{4} & Pendapat siswa tentang LAS & Frekuensi & Persentase & Frekuensi & Persen \\
\hline & Siswa memahami LAS & 31 & 93,33 & 2 & 6,67 \\
\hline & Siswa tertarik pada LAS & 31 & 93,33 & 2 & 6,67 \\
\hline & Rata-rata & 31 & 93,33 & 2 & 6,67 \\
\hline & Rata-rata Total & 31,625 & $\mathbf{9 5 , 5 5}$ & 1,375 & 4,45 \\
\hline
\end{tabular}

Penelitian ini dihentikan pada siklus ini karena hasil respon siswa dalam kegiatan pembelajaran dan terhadap perangkat pembelajaran diisi oleh siswa setelah kegiatan pembelajaran siklus II pada kategori "Sangat Baik" atau sudah mencapai $\geq 90 \%$. Hasil yang didapat sesuai dengan hasil yang diharapkan maka siklus II ini dihentikan.

Melalui Model pembelajaran kooperatif tipe STAD dengan metode Penemuan Terbimbing maka hasil belajar matematika siswa meningkat. Dalam proses belajar mengajar yang menerapkan model pembelajaran kooperatif tipe STAD dengan metode Penemuan Terbimbing ini aktivitas siswa menjadi perhatian guru. Berdasarkan observasi yang dilakukan pada tiap pertemuannya pada siklus I memperoleh persentase $73,55 \%$ dan pada siklus II hasilnya meningkat menjadi $85,75 \%$. Sehingga dapat bahwa aktivitas siswa meningkat dalam penerapan Model pembelajaran kooperatif tipe STAD dengan metode Penemuan Terbimbing di kelas VII-2 SMP Negeri 7 Padangsidimpuan. Adapun peningkatan aktivitas dari siklus I ke siklus II adalah sebesar 12,2 sehingga diperoleh peningkatan rata-rata aktivitas siswa sebesar 0,46 dengan kriteria sedang.

Melihat kekurangan yang masih ada pada aktivitas siswa terhadap pembelajaran pada siklus I belum memenuhi tolak ukur keberhasilan ditentukan maka penelitian dilanjutkan pada siklus II. Hal-hal yang harus diperbaiki pada tindakan siklus II adalah keikutsertaan siswa dalam kelompok 
Hasil angket respon Siswa selama diberikan tindakan pada siklus I diperoleh sebesar 79,64 pada kategori cukup baik. Selanjutnya pada siklus II terjadi peningkatan diperoleh kemampuan guru mengelola model pembelajaran kooperatif tipe STAD dengan metode Penemuan Terbimbing sebesar 95,55 dengan kriteria sangat baik. Sehingga dapat dikatakan bahwa respon siswa meningkat melalui penerapan Model pembelajaran kooperatif tipe STAD dengan metode Penemuan Terbimbing di kelas VII-2 SMP Negeri 7 Padangsidimpuan. Adapun peningkatan respon siswa dari siklus I ke siklus II adalah sebesar 15,9 sehingga diperoleh peningkatan ratarata aktivitas siswa sebesar 0,78 dengan kriteria tinggi.

\section{KESIMPULAN}

Berdasarkan tujuan penelitian, hasil penelitian dan pembahasan, dapat disimpulkan bahwa:

1. Meningkatnya hasil belajar matematika melalui penerapan model pembelajaran kooperatif tipe STAD Dengan metode penemuan terbimbing. Hal ini dapat ditunjukkan dengan persentase ketuntasan hasil belajar matematika yaitu 70,97\% pada siklus I menjadi $83,87 \%$ pada siklus II. Adapun peningkatan hasil belajar siswa sebesar 0,65 dengan kriteria sedang.

2. Meningkatnya aktivitas belajar siswa melalui penerapan model pembelajaran kooperatif tipe STAD dengan metode penemuan terbimbing. Hal ini ditunjukkan berdasarkan observasi yang dilakukan pada tiap pertemuannya pada siklus I memperoleh persentase $73,55 \%$ dan pada siklus II hasilnya meningkat menjadi $85,75 \%$. Adapun peningkatan aktivitas siswa sebesar 0,46 dengan kriteria sedang.

3. Meningkatnya respon siswa terhadap pembelajaran kooperatif tipe STAD dengan metode penemuan terbimbing. Hal ini dapat ditunjukkan bahwa berdasarkan hasil angket selama diberikan tindakan pada siklus I diperoleh sebesar 79,64 dan pada siklus II diperoleh sebesar 95,55. Adapun peningkatan respon siswa sebesar 0,78 dengan kriteria tinggi.

\section{DAFTAR RUJUKAN}

Isjoni. (2011). Cooperative Learning Mengembangkan Kemampuan Belajar Berkelompok. Bandung: Alfabet

Nurkancana, Wayan. (1986). Evaluasi Pendidikan. Bandung : Remaja Rosda Karya.

Putra, A., Syarifuddin, H., \& Zulfah, Z. (2018). Validitas Lembar Kerja Peserta Didik Berbasis Penemuan Terbimbing dalam Upaya Meningkatkan Pemahaman Konsep dan Kemampuan Penalaran Matematis. Edumatika : Jurnal Riset Pendidikan Matematika, 1(2), 56-62. doi:10.32939/ejrpm.v1i2.302

Slavin, R. (2005). Cooperative Learning Teori Riset dan Praktik. Bandung: Nusa Media

Trianto. (2009). Mendesain Model Pembelajaran Inovatif Progresif Konsep, Landasan, dan Implementasinya pada Kurikulum Tingkat Satuan Pendidikan (KTSP), Jakarta: Kencana. 